\title{
Impact of Polytechnic Education on Enterprenuership Development in Nigeria
}

\author{
Grema Maina Bukar ${ }^{1, *}$, Yohanna A. Timothy ${ }^{2, *}$ \\ ${ }^{1}$ Department of Business Management, Ramat Polytechnic, PMB 1070, Maiduguri, \\ Borno State, Nigeria \\ Phone: +2348032871134 \\ 2Department of Business Management, University of Maiduguri, PMB 1069, Maiduguri, \\ Borno State, Nigeria \\ Phone: +2348033938743 \\ *,**E-mail address: ggremari@gmail.com , ask4yat@gmail.com
}

\begin{abstract}
The consequential failures of breakeven in respect to business expectations in Northern Nigeria drive around the competent knowledge acquired by entrepreneurs. This knowledge can be translated into identifiable opportunities with lucrative business openings. As such impacting knowledge on Entrepreneurship Education to yield employment opportunities through the entrepreneurship development was the bases of this Research work. Survey Method was designed and used with Multistage sampling procedure. The responses were categorized into four Stages. (9) local governments were randomly selected from three (3) senatorial zones in Stage One. In the second stage, fifty (50) Ramat Polytechnics graduates engaged in Entrepreneurship businesses in the areas of Technical, Vocational, Businesses etc. courses were purposively selected from 27 local governments of the state. Descriptive statistic and five point likert scale were used to analyze the data. The result shows that; there were several types of entrepreneurs that are products of Polytechnic Education fastened in economic growth with employment opportunities created through the entrepreneurship development through expanding of businesses and poverty reduction. It was recommended that Entrepreneurship development should become part and parcel of tertiary Institutions' curriculum so that youngsters will acquire the necessary skills from the onset.
\end{abstract}

Keyword: Impact; Polytechnic; Development; Entrepreneurial

\section{INTRODUCTION}

In Nigeria today, the increasing rate of unemployment, corruption and so many other social problems become worrisome to the government and to every well meaning citizen. Therefore, the need apparent change is very desirable and necessary for the country to move to forge to ahead and to meet up with the global challenges. The integration of economies through globalization process any government or state that hesitates or vacillates on whether to imbibe the culture of change will certainly create standstill not only at the detriment of its country but to the larger global community.

The incidence of Poverty in Nigeria is on the high side, where $70 \%$ of the total population has been classified as poor (Nigeria Entrepreneurship Initiative, 2009; Ewhrudjakpor, 2008) 
This rate of poverty is however accentuated by the increasing rate of unemployment, high level of illiteracy, corruption and bad governance among others. They demanded that government provide them with jobs for them to cater for their essential needs of life (Dabalen, Oni and Adekola, 2000). It is pertinent to note that education can be a means to an end. It can simply be a tool for securing employment and emancipation of people through the provision and acquiring of necessary knowledge and skills to make lives more flourishing. The objective of this paper is to emphasize the need and importance of entrepreneurship education, which will serve as a panacea to some social economic problems. This study assessed the effects of Polytechnic Education in entrepreneurship development in Borno State, Nigeria.

One of the goals of economic development founded by successive governments particularly in developing economies have been the reduction of unemployment through entrepreneurial development (Bello, 2010). A cardinal thrust for the achievement of the objective has been the development of indigenous entrepreneurship through provision of enabling environment, technical education and financial assistance as well as skill acquisition opportunities (Musa, 2009).

Entrepreneurs have emerged as important agents of economic and social transformation in all countries of the world (Bello, 2010). Since the adoption of the economic reform programme in Nigeria in 1986, there has been a decisive switch of emphasis from the grandiose, capital intensive, large-scale industrial project based on the philosophy of import substitution to small scale industries with immense potentials for developing domestic linkages for rapid, sustainable industrial development (Musa, 2009).

Entrepreneurship development through education has been receiving attention globally. Several attempt have been made through researches, mounting of entrepreneurship courses, programmes in both institutions of learning and entrepreneurship research centers for the purpose of developing both entrepreneurship spirit and culture (Akpomi 2009; Adejimola and Olufunmilayo 2009; Dickson, Solomon and Weaver, 2008, Vincent and Farlow, 2008; Urbano, Aponte and Toledano, 2008; Poikkijoki and Heinonen, 2006; Fuchs, Werner and Wallau, 2008; Johnso, Craig and Hildebrand, 2006; Matlay, 2008, 2009; Solomon, 2007). In this regard, effort has to be intensified to mobilize and enhance entrepreneurial activity which will consequently benefit individuals, government, and the society at large. Poverty and Unemployment are among the major developmental problems that face every developing economy in the $21 \mathrm{st}$ century (Ewhrudjakpor, 2008).

\section{METERIAL AND METHOD}

The populations for this study were the respondents who have undergone Ramat Polytechnic Education engaged in Entrepreneurship businesses in Borno State, Nigeria. The sample for this study was the Ramat Polytechnic graduates engaged in Entrepreneurship businesses in Borno State, Nigeria. Multistage sampling procedure was employed for this study. In the first stage, three (3) local governments were randomly selected in each of the three (3) senatorial zones of the State. In the second stage, fifty (50) Ramat Polytechnics graduates engaged in Entrepreneurship businesses in the areas of Technical, Vocational, Businesses etc courses were purposively selected from the local governments. While in the third stage, a total of 300 respondents who were graduates of the Ramat Polytechnics Maiduguri operating various types of entrepreneurship businesses were randomly and proportionately selected and used for the analysis. 
The Study employed, Descriptive statistics, such as frequency, percentage and five point likert scale were used to analyze the data. The descriptive statistics used includes percentage and frequency. These were used to analyze the various types of entrepreneurships developed by Polytechnic Education; identify the problems faced by the Polytechnic in imparting knowledge on Entrepreneurship Education; and the employment opportunities created through the entrepreneurship development by the Polytechnic Education to achieve specific objective.

\section{REVIEW OF EMPHERICAL LITERATURE}

\section{The Concept and Development of Entrepreneurship}

A natural entrepreneur should have a vision of something new and a belief in it that is so strong that it becomes a reality; a touch of craziness; act instinctively; have ideas constantly bubbling and pushing up inside until they are forced out; The entrepreneur generally decides on the product, acquires the facilities and brings together the labour force, capital and production materials. If the business succeeds, the entrepreneur reaps the reward of the profits; and if it fails, he takes loss. In the view of Gana (2000).

Despite the apparent benefits, indications are that all is not well with entrepreneurship in Nigeria. One of the factors identified as barriers to entrepreneurship is the lack of seed capital (Oshagbemi, 1983). This is more acute in Nigeria with more than $70 \%$ of the entire Nigerian population living below poverty level (Bello, 2008).

Entrepreneurship has been recognized as an important aspect and functioning of organization and economies (Dickson, Solomon and Weaver, 2008). It contributes in an immeasurable ways toward creating new job, wealth creation, poverty reduction, and income generating for both government and individuals. Schumpeter in 1934 argued that entrepreneurship is very significant to the growth and development of economies (Keister, 2005). Education is undisputedly considered as the bedrock of any meaningful development (Akpomi, 2009), be it economic, social or political.

The Nigeria policy of education made it clear on the need for functional education, to be relevant, practical and acquisition of appropriate skills and development of competencies as equipment for the individuals to live in and contribute to the development of his/her society (Aladekomo,2004). Adejimola and Olufunmilayo (2009) reported that about $80 \%$ of the graduates find it difficult to get employment every year. And at the same time much has not been done in trying to bring collaboration between the entrepreneurs and the institutions. The universities, polytechnic and any other academic institution's community stands to benefit a lot from entrepreneurs out there. Opportunity entrepreneurship came into being as a result of exploiting certain opportunity that exist while on other hand necessity come as a respond to employment crisis, this necessitate second option of been self employment (Koster and Rai, 2009; Keister, 2005).

\section{Nigeria Educational Policy and Entrepreneurship}

The history of Nigeria education system could be traced back to the colonial period, the educational policy then was geared toward serving the interest of the colonial masters in term of supply of manpower for their effective administration of Nigeria colony and protectorates (Aladekomo, 2004).

However, In the 1981 National policy of education attempt has been made by the government to link the policy with the issue of self employment and the industrial policy. Thus higher education policy as stipulated is expectedly to cater for production scientist and technologist and absolutely none was directed for self employment but for the vacant positions 
in government or public offices (Aladekomo, 2004). In an attempt to ascertain the way forward and in response to the current socio-economic problems of the country as earlier mentioned, questions were raised by various people as to what is the right Technical and vocational institutions where designed largely to prepare technicians at occupational levels. Fakae (2005) asserted that "emphasis is on skill-acquisition and sound scientific knowledge, which gives ability to the use of hand and machine for the purpose of production that vocational education has not and cannot provide permanent solution to unemployment as some of us may believe. Onifade (2002) observed that "the threat of job scarcity and growing unemployment creates doubts and pessimism on the programmes of vocational technical schools and the education system in general".

Adamu (2008) asserted that the Nigeria University education, patterned after the "gold standard" of British colonial universities remains the highway to white collar jobs and social security for millions of Nigerians

the polytechnic sector in which a large number of people vehemently opposed to this development. According to Onukaogu (2008) "There is absolutely nothing wrong with a very well set out plan by the government to encourage the Nigerian child to pursue science subjects. In another development, Onifade (2002) pointed out that commonwealth Minister of Education in August 1988 and the Commonwealth Association of Polytechnics in Africa (CAPA) in 1991 opined that students in tertiary institutions should be taught entrepreneurship education in their final sessions.

It is believe that the current formal education is only aimed at making people to be the same in spite of the differences in them. This fact has been corroborated by Ingalla (1976); "It is becoming increasingly clear that formal schooling in our society generally aims at creating sameness and not difference. The members of class, for example, are graded on the basis of how well they each acquire the same information presented in same way to all.

\section{Entrepreneurial Education and National Development}

The need of education in the developmental effort of any nation cannot be underestimated. The development of educational sector is sine-qua non for the development in all other sectors. Barnabas and Durkwa (2007) asserted that "development in any society is anchored primarily to education process". Sule (2004) is of the opinion that education is a sure pathway to liberation of the mind and the improvement of socio economic status of people. It also follows that education and training help individuals to be empowered and escape poverty by providing them with the skills and knowledge to raise their output, income and wealth (Aliu, 2007). In the light of the above stated facts, various government and international agencies are making serious effort in both developed and underdeveloped to optimally develop the education Sector

According to Essien (2004), "sustainable development has to do with meeting the needs of the present generation without denying future generation access to the same natural resources for their own needs".

The development here is appraised in terms of both redistribution of wealth and meeting the basic needs of the masses at sustainable level. This means that it must be sustained to be able to impact and change the life and living of the masses (Kazaure and Danmallam, 2006).

\section{Developing and Supporting Entrepreneurial Careers/Selection in School}

There is much effort and enthusiasm to teach entrepreneurship course using wide range of method such as venture creation by students, developing formal business plan, creating out feasibility study etc.(Vincett and Farlow, 2008; Dickson, Solomon and Weaver, 2008 ). 
acquisition of necessary competencies to sense of self reliance, independence, youth empowerment and of course poverty reduction (Akpomi,2009). In their opinion Adejimola and Olufunmilayo (2009) lamented that "even in the developed countries education system emphasizes the trial of inquiry -discovery application in teaching'. The task of Universities and other institutions where entrepreneurship education need to be taught,

This appropriate human capital or resource space is the ideal educational environment for producing individuals with a mindset of self-reliant, creativity and high productivity ready to cope with the 21 st century world of work (Aliu, 2007). Perhaps the Government may have to take the lead, at least at first so that other will follow suit (McConnell and Brue, 2002). Sagagi (2007) stated that "fostering an environment that encourages entrepreneurs to invest in technology and new activities is critical to the required economic growth in Nigeria

\section{RESULT PRESENTATION}

Table 1. Types of entrepreneurship developed by polytechnic education.

\begin{tabular}{|c|c|c|}
\hline Types of entrepreneurship & Frequency & Percentage \\
\hline Mechanical workshop & 129 & 43 \\
\hline Building and construction & 53 & 17.7 \\
\hline Provisions store & 29 & 9.4 \\
\hline Manufacturing industries & 10 & 3.3 \\
\hline Animal husbandry & 79 & 26.3 \\
\hline Total & 300 & 100 \\
\hline
\end{tabular}

Source: Field Survey, 2012

Table 2. Constraining Factors to Entrepreneurship Development by the Polytechnic Education.

\begin{tabular}{|c|c|c|c|c|c|c|c|}
\hline S/N & $\begin{array}{c}\text { Constraining } \\
\text { factors }\end{array}$ & $\begin{array}{c}\text { Strongly } \\
\text { agreed }\end{array}$ & Agreed & $\begin{array}{c}\text { Strongly } \\
\text { disagreed }\end{array}$ & Disagreed & Undecided & Total \\
\hline i. & $\begin{array}{c}\text { Inadequate } \\
\text { finance }\end{array}$ & $\begin{array}{c}60 \\
(20)\end{array}$ & $\begin{array}{c}117 \\
(39)\end{array}$ & $\begin{array}{c}35 \\
(11.7)\end{array}$ & $\begin{array}{c}48 \\
(16)\end{array}$ & $\begin{array}{c}40 \\
(13.3)\end{array}$ & $\begin{array}{c}300 \\
(100)\end{array}$ \\
\hline ii. & $\begin{array}{c}\text { Ignorance of } \\
\text { institutionalize } \\
\text { incentive }\end{array}$ & $\begin{array}{c}44 \\
(14.7)\end{array}$ & $\begin{array}{c}70 \\
(23.3)\end{array}$ & $\begin{array}{c}87 \\
(27)\end{array}$ & $\begin{array}{c}59 \\
(19.7)\end{array}$ & $\begin{array}{c}40 \\
(13.3)\end{array}$ & $\begin{array}{c}300 \\
(100)\end{array}$ \\
\hline iii. & $\begin{array}{c}\text { High rate of } \\
\text { business } \\
\text { mortality }\end{array}$ & 63 & $\begin{array}{c}98 \\
(21)\end{array}$ & $\begin{array}{c}74 \\
(32.7)\end{array}$ & $\begin{array}{c}40 \\
(24.7)\end{array}$ & $\begin{array}{c}25 \\
(13.3)\end{array}$ & $\begin{array}{c}300 \\
(8.3)\end{array}$ \\
\hline iv. & $\begin{array}{c}\text { inadequate } \\
\text { trained } \\
\text { personnel }\end{array}$ & $\begin{array}{c}53 \\
(17.7)\end{array}$ & $\begin{array}{c}129 \\
(43)\end{array}$ & $\begin{array}{c}11 \\
(3.7)\end{array}$ & $\begin{array}{c}79 \\
(26.3)\end{array}$ & $\begin{array}{c}28 \\
(9.3)\end{array}$ & $\begin{array}{c}300 \\
(100)\end{array}$ \\
\hline v. & $\begin{array}{c}\text { Restricted } \\
\text { market }\end{array}$ & $\begin{array}{c}21 \\
(7)\end{array}$ & $\begin{array}{c}69 \\
(23)\end{array}$ & $\begin{array}{c}109 \\
(36.3)\end{array}$ & $\begin{array}{c}53 \\
(17.7)\end{array}$ & $\begin{array}{c}48 \\
(16)\end{array}$ & $\begin{array}{c}300 \\
(100)\end{array}$ \\
\hline
\end{tabular}




\begin{tabular}{|c|c|c|c|c|c|c|c|}
\hline vi. & $\begin{array}{c}\text { Lack technical } \\
\text { advice }\end{array}$ & $\begin{array}{c}48 \\
(16)\end{array}$ & $\begin{array}{c}59 \\
(19.7)\end{array}$ & $\begin{array}{c}80 \\
(26.7)\end{array}$ & $\begin{array}{c}75 \\
(25)\end{array}$ & $\begin{array}{c}38 \\
(12)\end{array}$ & $\begin{array}{c}300 \\
(100)\end{array}$ \\
\hline vii. & $\begin{array}{c}\text { Lack of } \\
\text { efficiency }\end{array}$ & $\begin{array}{c}40 \\
(13.3)\end{array}$ & $\begin{array}{c}100 \\
(33.3)\end{array}$ & $\begin{array}{c}82 \\
(27.3)\end{array}$ & $\begin{array}{c}44 \\
(14.7)\end{array}$ & $\begin{array}{c}34 \\
(11.3)\end{array}$ & $\begin{array}{c}300 \\
(100)\end{array}$ \\
\hline viii. & $\begin{array}{c}\text { Aversion to } \\
\text { ownership } \\
\text { dilution }\end{array}$ & $\begin{array}{c}53 \\
(13.3)\end{array}$ & $\begin{array}{c}68 \\
(22.7)\end{array}$ & $\begin{array}{c}75 \\
(25)\end{array}$ & $\begin{array}{c}94 \\
(31.3)\end{array}$ & $\begin{array}{c}10 \\
(3.3)\end{array}$ & $\begin{array}{c}300 \\
(100)\end{array}$ \\
\hline ix. & $\begin{array}{c}\text { Poor accounting } \\
\text { and record } \\
\text { keeping }\end{array}$ & $\begin{array}{c}93 \\
(31)\end{array}$ & $\begin{array}{c}112 \\
(37.3)\end{array}$ & $\begin{array}{c}30 \\
(10)\end{array}$ & $\begin{array}{c}41 \\
(13.7)\end{array}$ & $\begin{array}{c}24 \\
(8)\end{array}$ & $\begin{array}{c}300 \\
(100)\end{array}$ \\
\hline x. & $\begin{array}{c}\text { Diversion of } \\
\text { business fund }\end{array}$ & $\begin{array}{c}81 \\
(27)\end{array}$ & $\begin{array}{c}73 \\
(24.3)\end{array}$ & $\begin{array}{c}49 \\
(16.3)\end{array}$ & $\begin{array}{c}63 \\
(21)\end{array}$ & $\begin{array}{c}34 \\
(11.3)\end{array}$ & $\begin{array}{c}300 \\
(100)\end{array}$ \\
\hline xi. & $\begin{array}{c}\text { Poor } \\
\text { infrastructural } \\
\text { facilities }\end{array}$ & $\begin{array}{c}40 \\
(13.3)\end{array}$ & $\begin{array}{c}105 \\
(35)\end{array}$ & $\begin{array}{c}84 \\
(28)\end{array}$ & $\begin{array}{c}20 \\
(6.7)\end{array}$ & $\begin{array}{c}51 \\
(17)\end{array}$ & $\begin{array}{c}300 \\
(100)\end{array}$ \\
\hline xii. & $\begin{array}{c}\text { Inadequate and } \\
\text { unharmonized } \\
\text { incentive }\end{array}$ & $\begin{array}{c}39 \\
(13)\end{array}$ & $\begin{array}{c}79 \\
(26.3)\end{array}$ & $\begin{array}{c}63 \\
(21)\end{array}$ & $\begin{array}{c}57 \\
(19)\end{array}$ & $\begin{array}{c}62 \\
(20.7)\end{array}$ & $\begin{array}{c}300 \\
(100)\end{array}$ \\
\hline xiii. & $\begin{array}{c}\text { Lack of } \\
\text { appropriate } \\
\text { technologies }\end{array}$ & $\begin{array}{c}70 \\
(23.3)\end{array}$ & $\begin{array}{c}109 \\
(36.3)\end{array}$ & $\begin{array}{c}43 \\
(14.3)\end{array}$ & $\begin{array}{c}38 \\
(12.7)\end{array}$ & $\begin{array}{c}40 \\
(13.3)\end{array}$ & $\begin{array}{c}300 \\
(100)\end{array}$ \\
\hline xiv. & $\begin{array}{c}\text { Lack of seed } \\
\text { capital }\end{array}$ & $\begin{array}{c}71 \\
(23.7)\end{array}$ & $\begin{array}{c}82 \\
(27.3)\end{array}$ & $\begin{array}{c}52 \\
(17.3)\end{array}$ & $\begin{array}{c}49 \\
(16.3)\end{array}$ & $\begin{array}{c}46 \\
(15.3)\end{array}$ & $\begin{array}{c}300 \\
(100)\end{array}$ \\
\hline
\end{tabular}

Source: Field Survey, 2012

Table 3. Facilitating Factors to entrepreneurship development by polytechnic education.

\begin{tabular}{|c|c|c|c|c|c|c|c|}
\hline S/N & $\begin{array}{c}\text { Facilitating } \\
\text { factors }\end{array}$ & $\begin{array}{c}\text { Strongly } \\
\text { agreed }\end{array}$ & Agreed & $\begin{array}{c}\text { Strongly } \\
\text { disagreed }\end{array}$ & Disagreed & Undecided & Total \\
\hline i. & $\begin{array}{c}\text { Operating } \\
\text { independent } \\
\text { business }\end{array}$ & $\begin{array}{c}79 \\
(26.3)\end{array}$ & $\begin{array}{c}83 \\
(27.7)\end{array}$ & $\begin{array}{c}44 \\
(14.7)\end{array}$ & $\begin{array}{c}32 \\
(10.7)\end{array}$ & $\begin{array}{c}62 \\
(20.6)\end{array}$ & $\begin{array}{c}300 \\
(100)\end{array}$ \\
\hline ii. & $\begin{array}{c}\text { Fastening } \\
\text { economic } \\
\text { growth }\end{array}$ & $\begin{array}{c}83 \\
(27.7)\end{array}$ & $\begin{array}{c}102 \\
(34)\end{array}$ & $\begin{array}{c}60 \\
(20)\end{array}$ & $\begin{array}{c}29 \\
(9.7)\end{array}$ & $\begin{array}{c}26 \\
(8.6)\end{array}$ & $\begin{array}{c}300 \\
(100)\end{array}$ \\
\hline iii. & $\begin{array}{c}\text { Increasing } \\
\text { productivity }\end{array}$ & $\begin{array}{c}74 \\
(24.7)\end{array}$ & $\begin{array}{c}138 \\
(46)\end{array}$ & $\begin{array}{c}49 \\
(16.3)\end{array}$ & $\begin{array}{c}10 \\
(3.3)\end{array}$ & $\begin{array}{c}29 \\
(9.7)\end{array}$ & $\begin{array}{c}300 \\
(100)\end{array}$ \\
\hline iv. & $\begin{array}{c}\text { Creating new } \\
\text { technology }\end{array}$ & $\begin{array}{c}101 \\
(33.7)\end{array}$ & $\begin{array}{c}124 \\
(41.3)\end{array}$ & $\begin{array}{c}23 \\
(7.7)\end{array}$ & $\begin{array}{c}12 \\
(4)\end{array}$ & $\begin{array}{c}40 \\
(13.3)\end{array}$ & $\begin{array}{c}300 \\
(100)\end{array}$ \\
\hline v. & $\begin{array}{c}\text { Generating } \\
\text { market } \\
\text { competition }\end{array}$ & $(24.3)$ & $(31.7)$ & $(16.3)$ & $(12.3)$ & $(15.3)$ & \begin{tabular}{c}
$(100)$ \\
\hline
\end{tabular} \\
\hline
\end{tabular}

Source: Field Survey, 2012 
Table 4. Major Problems Faced by the Polytechnic in Imparting Knowledge on Entrepreneurship Education.

\begin{tabular}{|c|c|c|c|}
\hline $\mathbf{S} / \mathbf{N}$ & Major Problems & Frequency & Percentage \\
\hline i. & $\begin{array}{c}\text { Policies and new curriculum are not in line with } \\
\text { demand for imparting knowledge on } \\
\text { entrepreneurship }\end{array}$ & 43 & 14.3 \\
\hline ii. & $\begin{array}{l}\text { Selection of entrepreneurship by the student is } \\
\text { as a matter of opportunity }\end{array}$ & 24 & 8 \\
\hline iii. & $\begin{array}{l}\text { Most of the polytechnic educational policies } \\
\text { failed to take issue of self employment }\end{array}$ & 34 & 11.3 \\
\hline iv. & $\begin{array}{l}\text { Inadequate instructional facilities to provide the } \\
\text { technical knowledge and vocational skills } \\
\text { necessary for agricultural, industrial, } \\
\text { commercial and economic development }\end{array}$ & 53 & 17.7 \\
\hline v. & $\begin{array}{l}\text { Poor educational background of the students to } \\
\text { have better intelligent understanding of the } \\
\text { increasing complexity of technology }\end{array}$ & 41 & 13.7 \\
\hline vi. & $\begin{array}{l}\text { To revisit the ratio of } 70 \% \text { science and } 30 \% \\
\text { arts policies in the polytechnic sector creates } \\
\text { discomfort and feeling of inferiority on part of } \\
\text { students studying arts and humanities }\end{array}$ & 63 & 21 \\
\hline vii. & $\begin{array}{l}\text { There is still unprecedented increasing number } \\
\text { graduate without corresponding vacancies }\end{array}$ & 31 & 10.3 \\
\hline viii. & $\begin{array}{l}\text { The current formal education is only aimed at } \\
\text { making people to be the same in spite of the } \\
\text { differences in them. }\end{array}$ & 11 & 3.7 \\
\hline & Total & 300 & 100 \\
\hline
\end{tabular}

Source: Field Survey, 2012

Table 5. Employment Opportunities created through the Entrepreneurship Development by the Polytechnic Education.

\begin{tabular}{|c|c|c|c|}
\hline S/N & Employment opportunities & Frequency & Percentage \\
\hline i. & Growth and development of economies & 44 & 14.7 \\
\hline ii. & Wealth creation by expanding businesses & 74 & 24.7 \\
\hline iii. & Poverty reduction among individuals & 80 & 26.6 \\
\hline iv. & $\begin{array}{c}\text { Income generating for both government and } \\
\text { individuals }\end{array}$ & 42 & 26.6 \\
\hline
\end{tabular}




\begin{tabular}{|c|c|c|c|}
\hline v. & $\begin{array}{c}\text { Creating new job for unemployed polytechnic } \\
\text { graduates }\end{array}$ & 60 & 20 \\
\hline & Total & $\mathbf{3 0 0}$ & $\mathbf{1 0 0}$ \\
\hline
\end{tabular}

Source: Field Survey, 2012

\section{RESULT AND DISCUSSION}

The types of entrepreneurship developed by polytechnic education identified include mechanical workshop, building and construction, provisions store, manufacturing industries and animal husbandry. The findings are presented in Table 1 shows that most $43 \%$ of the respondents indicated mechanical workshop as the type entrepreneurship they are operating, $17.7 \%$ indicated building and construction, $9.7 \%$ sale provision store, $3.3 \%$ have manufacturing industries, while $26.3 \%$ indicated animal husbandry in the study area. This implies that most of the respondents have mechanical workshop as their entrepreneurship in the study area.

The constraining and facilitating factors to entrepreneurship development by the Polytechnic education were examined and Analyzed in Table 2 which shows that $20 \%$ of the respondents strongly agreed that inadequate finance was a constraining factor, $39 \%$ agreed, $17.7 \%$ strongly disagreed, $16 \%$ disagreed, while $13.3 \%$ undecided. This indicates that most of the respondents agreed that inadequate finance is a constraining factor to entrepreneurship development by the Polytechnic education in the study area. Inadequate finance limits the scope investment by an entrepreneur.

The result also shows that $14.7 \%$ of the respondents strongly agreed that ignorance of institutionalized incentive was a constraining factor, $23.5 \%$ agreed, $27 \%$ strongly disagreed, $19.7 \%$ disagreed, while $13.3 \%$ undecided. This means most of the respondents strongly disagreed that ignorance of institutionalized incentive was a constraining factor to entrepreneurship development by the Polytechnic education in the study area.

In another direction the, finding indicates that $21 \%$ of the respondent strongly agreed that high rate of business mortality was a constraining factor, $32.7 \%$ agreed, $24.7 \%$ strongly disagreed, $13.3 \%$ disagreed, while $8.3 \%$ undecided. This implies that most of the respondents agreed that high rate of business mortality was a constraining factor to entrepreneurship development by the Polytechnic education in the study area.

The result also indicates that $17.7 \%$ of the respondents strongly agreed that inadequate trained personnel was a constraining factor, most $43 \%$ agreed, $3.7 \%$ strongly disagreed, 26.3 $\%$ disagreed, while $9.3 \%$ undecided.

This implies that most of the respondents agreed that inadequate trained personnel were a constraining factor to entrepreneurship development by the Polytechnic education in the study area. The reason is obvious, inadequate trained personnel will affect the entrepreneurs' quality of service rendered to clients.

The finding indicates that $7 \%$ of the respondents strongly agreed that restricted market was a constraining factor, $23 \%$ agreed, $36.3 \%$ strongly disagreed, $17.7 \%$ disagreed, while 16 $\%$ undecided. This reveals that most of respondents strongly disagreed that restricted market was a constraining factor to entrepreneurship development by the Polytechnic education in the study area. The result shows that $16 \%$ of the respondents strongly agreed that lack of technical advice was a constraining factor, $19.7 \%$ agreed, $26.7 \%$ strongly disagreed, $25 \%$ disagreed, while $12 \%$ undecided. This indicates that most of the respondents strongly disagreed that lack 
of technical advice was a constraining factor to entrepreneurship development by the Polytechnic education in the study area.

It was discovered that $13.3 \%$ of the respondents strongly agreed that lack of efficiency was a constraining factor, $33.3 \%$ agreed, $27.3 \%$ strongly disagreed, $14.7 \%$ disagreed, while $11.3 \%$ undecided. This implies that most of the respondents agreed that lack of efficiency was a constraining factor to entrepreneurship development by the Polytechnic education in the study area That shows that $17.7 \%$ of the respondents strongly agreed that aversion to ownership dilution was a constraining factor, $22.7 \%$ agreed, $25 \%$ strongly disagreed, $31.3 \%$ disagreed, while $3.3 \%$ undecided. This indicates that most of the respondents disagreed that aversion to ownership dilution was a constraining factor to entrepreneurship development by the Polytechnic education in the study area.

Another $31 \%$ of the respondents strongly agreed that poor accounting and record keeping was a constraining factor, $37.3 \%$ agreed, $10 \%$ strongly disagreed, $13.7 \%$ disagreed, while 8 $\%$ undecided. This shows that most of the respondents agreed that poor accounting and record keeping was a constraining factor to entrepreneurship development by the Polytechnic education in the study area.

The result shows that $27 \%$ of the respondents strongly agreed that diversion of business fund was a constraining factor, $24.3 \%$ agreed, $16.3 \%$ strongly disagreed, $21 \%$ disagreed, while $11.3 \%$ undecided.

This reveals that most of the respondents strongly agreed that diversion of business fund was a constraining factor to entrepreneurship development by the Polytechnic education in the study area. That that $13.3 \%$ of the respondents strongly agreed that poor infrastructural facility was a constraining factor, $35 \%$ agreed, $28 \%$ strongly disagreed, $6.7 \%$ disagreed, while $17 \%$ undecided. This indicates that most of the respondents agreed that a poor infrastructural facility was a constraining factor to entrepreneurship development by the Polytechnic education in the study area.

Some of the inadequacies rated $13 \%$ of the respondents strongly agreed that inadequate and unharmonized incentives were constraining factors, $26.3 \%$ agreed, $21 \%$ strongly disagreed, $19 \%$ disagreed, while $20.7 \%$ undecided. This shows that most of the respondents agreed that inadequate and unharmonized incentives were constraining factors to entrepreneurship development by the Polytechnic education in the study area. The result also shows that $23.3 \%$ of the respondents strongly agreed that lack of appropriate technologies were constraining factors, $36.3 \%$ agreed, $14.3 \%$ strongly disagreed, $12.7 \%$ disagreed, while 13.3 $\%$ undecided.

This implies that most of the respondents agreed that lack of appropriate technologies were constraining factors to entrepreneurship development by the Polytechnic education in the study area. The result indicates that $23.7 \%$ of the respondents strongly agreed that lack of seed capital was a constraining factor, $27.3 \%$ agreed, $17.3 \%$ strongly disagreed, $16.3 \%$ disagreed, while $15.3 \%$ undecided. This implies that most of the respondents agreed that lack of seed capital was a constraining factor to entrepreneurship development by the Polytechnic education in the study area.

The facilitating factors to entrepreneurship development by the Polytechnic education were identified. Analysis of the result in Table 3 shows that $26.3 \%$ of the respondents strongly agreed that operating independent business was a facilitating factor, $27.7 \%$ agreed, $14.7 \%$ strongly disagreed, $10.7 \%$ disagreed, while $20.6 \%$ undecided. This implies that most of the respondents agreed that operating independent business was a facilitating factor to entrepreneurship development by the Polytechnic education in the study area. The result also shows that $27.7 \%$ of the respondents strongly agreed that fastening economic growth was a 
facilitating factor, $34 \%$ agreed, $20 \%$ strongly disagreed, $9.7 \%$ disagreed, while $8.6 \%$ undecided. This indicates that most of the respondents agreed that fastening economic growth was a facilitating factor to entrepreneurship development by the Polytechnic education in the study area.

The result reveals that $24.7 \%$ of the respondents strongly agreed that increasing productivity was a facilitating factor, most $46 \%$ agreed, $16.3 \%$ strongly disagreed, $3.3 \%$ disagreed, while $9.7 \%$ undecided. This reveals that most of the respondents agreed that increasing productivity was a facilitating factor to entrepreneurship development by the Polytechnic education in the study area.

The result also indicates that $33.7 \%$ of the respondents strongly agreed that creating new technology was a facilitating factor, most $41.3 \%$ agreed, $7.7 \%$ strongly disagreed, $4 \%$ disagreed, while $13.3 \%$ undecided. This shows that most of the respondents agreed that creating new technology was a facilitating factor to entrepreneurship development by the Polytechnic education in the study area. The finding also shows that $24.3 \%$ of the respondents strongly agreed that generating market competition was a facilitating factor, $31.7 \%$ agreed, $16.3 \%$ strongly disagreed, $12.3 \%$ disagreed, while $15.3 \%$ undecided. This implies that most of the respondents agreed that generating market competition was a facilitating factor to entrepreneurship development by the Polytechnic education in the study area.

Major problems faced by the Polytechnics in imparting knowledge on entrepreneurship education were identified in Table 4, Analysis of the result in the Table 4 shows that $14.3 \%$ of the respondents indicated that policies and new curriculum not in line with demand for imparting knowledge on entrepreneurship was the major problem faced by the Polytechnic in imparting entrepreneurship education, $8 \%$ said selection of entrepreneurship by the student is as a matter of opportunity, $11.3 \%$ said the polytechnic educational policies failed to take issue of self employment, $17.7 \%$ indicated inadequate instructional facilities to provide the technical knowledge and vocational skills necessary for agricultural, industrial commercial and economic development, $13.7 \%$ said poor educational background of the students to have better intelligent understanding of the increasing complexity of technology, $21 \%$ indicated the revisit of $70 \%$ science and $30 \%$ arts policies in the polytechnic sector creates discomfort and feeling of inferiority on the part students studying arts and humanities, $10.3 \%$ said there is unprecedented increasing number graduates without corresponding vacancies, while $3.7 \%$ said the current formal education is only aimed at making people to be the same in spite of their differences in the study area.

This implies that revisit of $70 \%$ science and $30 \%$ arts policies in the polytechnic sector creates discomfort and feeling of inferiority on the part students studying arts and humanities was a major problem faced by the Polytechnic in imparting entrepreneurship education in the study area.

The employment opportunities created through the entrepreneurship development by the polytechnic education were examined. The findings are presented in Table 5 Analysis of the result in Table 5 shows that $14.7 \%$ of the respondents indicated employment opportunities created through the entrepreneurship development by the Polytechnic Education were growth and development of economies, $24.7 \%$ said wealth creation by expanding business, $26.6 \%$ indicated poverty reduction among individuals, $14 \%$ said income generation for both government and individuals, while $20 \%$ indicated creating new jobs to employ polytechnic graduates were the employment opportunities created through the entrepreneurship development by the Polytechnic Education 


\section{CONCLUSION}

The study concludes that most of the respondents have mechanical workshop as their entrepreneurship and agreed that inadequate finance, high rate of business mortality, inadequate trained personnel, lack of efficiency, poor accounting and record keeping, poor infrastructural facility were constraining factor entrepreneurship development by the Polytechnic education in the study area. Another proportion of the respondents strongly agreed that diversion of business fund, while some strongly disagreed that ignorance of institutionalized incentive, restricted market, lack of technical advice and aversion to ownership dilution were constraining factor entrepreneurship development by the Polytechnic education in the study area.

The study also concludes that most of the respondents agreed that operating independent business, fastening economic growth, increasing productivity, creating new technology and generating market competition were facilitating factor to entrepreneurship development by the Polytechnic education in the study area. The revisit of $70 \%$ science and $30 \%$ arts policies in the polytechnic sector creates discomfort and feeling of inferiority on the part students studying arts and humanities was the major problem faced by the Polytechnic in imparting entrepreneurship education in the study area. Growth and development of economies, wealth creation by expanding business, poverty reduction among individuals, income generation for both government and individuals and creating new jobs to employ polytechnic graduates were the employment opportunities created through the entrepreneurship development by the Polytechnic Education in the study area.

\section{References}

[1] Adamu U. A (2008). Motionless Points in Chaos: Education Reforms, innovations and the challenges for Tertiary Education in Nigeria. Paper presented at the 1st National conference organized by Kano State Polytechnic.

[2] Adejimola A. S., Olufunmilayo T., African journal of Business Management 1(3) (2009) 80-88.

[3] Akpomi M. E., European Journal of Social Sciences 8(1) (2009)152-159.

[4] Aladekomo F. O., Journal of Social Science 9(2) (2004) 75-8.

[5] Aliu S. (2007), Entrepreneurship Education: An Overview Teacher's Guide on Entrepreneurship Education for Polytechnic and Monotechnics in Nigeria.

[6] Anyanwu E. (1997). Poverty in Nigeria: Concepts and Measurement and Determinants. In Poverty Alleviation in Nigeria. Proceedings of the 1997 Annual Conference of the Nigeria Economic Society.

[7] Barnabas P. A., Darkwa F. S., Distance Learning Education as Women Empowerment Strategy in Nigeria. International Journal of Research Education 1(2) (2007).

[8] Bello G. B. (2008). The Role of the Business Community in the War Against Poverty in Nigeria. In Duze, M.C et al, Poverty in Nigeria: Causes, Manifestations and Alleviation Strategies (eds). Adonis and Abbey Publishers Ltd, London.

[9] Bello G. B., Assessment of Government Initiatives on Entrepreneurship Development and Poverty Alleviation in Nigeria. Journal of Finance and Accounting Research 2(2) (2010).

[10] Dabalen A., Oni B., Adekola D. A. (2000), Labour Market: Prospects of University. 
[11] Graduates in Nigeria. A Background Study conducted to inform the design of the Nigeria University System Innovation Project. Retrieved from http://siteresource.worldbank.org on 22nd February, 2009.

[12] Dickson,P. H., Solomon G. T., Weaver K. M., Journal of small business and enterprise development 15(2) (2008) 239-258.

[13] Essien U. S. (2004). Mapping in Nigeria: Policy Options for National Development. A Research Project submitted to NIPSS.

[14] Ewhrudjakpor C., Journal of International social work 51(4) (2008) 519-531.

[15] Fakae D. B. (2005), Technical Education: An Overview of the Learning Process. Capacity Building of Workshop for Lecturers of Polytechnics and Monotechnics in Nigeria for Higher Competence and Productivity Education Trust Fund.

[16] Federal Ministry of Land and Survey (2010). Federal Ministry of Land and Survey (FMLS) Abuja, Nigeria. Office Memo File.

[17] Folorunsho O. A. (2006). Agriculture Development in Borno State: Problem and Prospects. An Invited Paper Delivered at the First Borno State Economic Submit held at International Conference Centre, Musa Usman Secretariat, Maiduguri May 6-11, 2001. Pp. 1-17.

[18] Fuchs K., Werner A., Wallau F., Journal of small business and enterprise development 15(2) (2008) 365-381.

[19] Gana J. S. (1995). Entrepreneurship. Joefegan Associates, Jos, Nigeria.

[20] Gana J. S. (2000). Entrepreneurship. $2^{\text {nd }}$ Ed., Joefegan Associates, Jos, Nigeria.

[21] Hisrich, R. D., Peter, M. P. \& Shepherd, D. A. (2007), Entrepreneurship (6th edition). McGraw Hill International, USA.

[22] Inegbenebor A. U (1989). Entrepreneurship. In Ejiofor, P. (eds.), Foundation of Business Administration. African Feb Publishers Ltd, Onitsha.

[23] Ingalla J. D. (1976). Human energy - The critical factor for individuals and Organization. Addison Wesley publishing coy.inc.philippines.

[24] Johnson D., Craig J. B. L., Hildabrand R., Journal of Management development 25(1) (2006) 40-54.

[25] Kazaure M. A., Dan Malam R. M. (2006), Technical \& Vocational Education: Tool for Nigeria's Socio-Economic Development.

[26] Keister L. A. (2005). Entrepreneurship. Elsevier Ltd, Netherland (ed)

[27] Koster S., Kumar Rai S., Journal of entrepreneurship 17(2) (2009) 117-137.

[28] Matlay H., Journal of small business and enterprise development 15(2) (2008) 3825-396.

[29] Matlay H., Journal of small business and enterprise development 16(2) (2009) 355-368.

[30] McConnell C. R., Brue S. L. (2002). Macroeconomics Principles, Problems and Policies. McGraw-Hill Irwin USA.

[31] MLS (2008). Ministry of Land and Survey Maiduguri, Borno State Office Memo File. 
[32] Muhammad A. D. K (2008). Polytechnic Sector under the current education reform. A Paper presented at the 1st National conference organized by Kano State Polytechnic.

[33] Musa A. (2009). Critical Assessment of Government Initiatives on Entrepreneurship Development and Poverty Eradication. A Case Study of NEEDS. An MBA Project Submitted to the Department of Business Administration, Bayero University, Kano.

[34] National Population Commission (NPC) (2006). Population Census Data Borno State, Nigeria. Federal Republic of Nigeria Official Gazette, national and State Provisional Total Census. Printed and published in 2007 by the Federal Government Printer, Lagos, Nigeria. 94 (21); 175-198.

[35] Onifade A. (2002). Unemployment in Nigeria: A Care for Self-Employment Education In Tertiary Institutions.

[36] Onukaogu A. A. (2008). Crisis in Nigeria's educational system. Being the first inaugural lecture delivered in Abia state polytechnic, Aba

[37] Oshagbemi A. T. (1983). Small Business Management in Nigeria. Longman Publishers, Lagos.

[38] Poikkijoki S., Heinonen J., Journal of management development 25(1) (2006) 80-94.

[39] Sagagi M. S. (2007). Change Management and Competitiveness: the Challenge for Entrepreneurship Education. A paper presented at a workshop on Entrepreneurship Education for Polytechnics and Monotechnics in Nigeria organized by NBTE.

[40] Solomon G., Journal of small business and enterprise development 14(2) (2007) 168-182.

[41] Sule M. N. (2004). Sociology of Education in Perspective, Deka Publishers, Jos.

[42] Urbano D., Aponte M., Toledano N., Journal of small business and enterprise development 15(2) (2008) 336-347.

[43] Vincett P. S., Farlow S., Journal of small business and enterprise development 15(2) (2008) 274-288. 